\title{
European wild forest reindeer and wolves: endangered prey and predators
}

\author{
Ilpo Kojola1, Johanna Tuomivaara1, Samuli Heikkinen¹, Kalevi Heikura², \\ Kauko Kilpeläinen ${ }^{3}$, Jukka Keränen ${ }^{3}$, Antti Paasivaara ${ }^{1}$ \& Vesa Ruusila ${ }^{4}$
}

\author{
1) Finnish Game and Fisheries Research Institute, Oulu Game and Fisheries Research, Tutkijantie \\ 2 E, Fl-90570 Oulu, Finland (email: ilpo.kojola@rktl.fi) \\ 2) University of Oulu, Zoological Museum, P.O. Box 3000, Fl-90014 Oulu, Finland \\ 3) Game Management District of Kainuu, Syväyksenkatu 1 B 27, Fl-89600 Suomussalmi, Finland \\ 4) Finnish Game and Fisheries Research Institute, Box 2, Fl-00721 Helsinki, Finland
}

Received 6 Nov. 2008, revised version received 24 Feb 2009, accepted 25 Feb. 2009

Kojola, I., Tuomivaara, J., Heikkinen, S., Heikura, K., Kilpeläinen, K., Keränen, J., Paasivaara, A. \& Ruusila, V. 2009: European wild forest reindeer and wolves: endangered prey and predators. Ann. Zool. Fennici 46: 416-422.

\begin{abstract}
Managers are sometimes faced with a situation where one endangered species increases the vulnerability of another one. According to our late-winter helicopter survey of Finland's two small populations of wild-forest reindeer (Rangifer tarandus fennicus), the eastern one decreased by half during the last 7 years. This is probably due to the return of the wolf (Canis lupus) to the area. Our data show that the annual recruitment rate of reindeer is strongly correlated with wolf density. Calf mortality was high and stable during the first months after birth. The wolf is classified as an endangered species in Finland. Thereby, our study area provides an example of a triggered situation in which a locally abundant, endangered predator increases the vulnerability of a threatened prey. There are basically two policy options for avoiding extinction: (1) to directly control the predation risk or (2) to reach further out into the ecosystem to control those factors that have led to high abundance of predators. One potential direct management action is increased wolf control in the primary summer home ranges of female reindeer. In the long term, wolf predation on wild-forest reindeer would decline if the abundance of moose (Alces alces) could be lowered, because high moose density supports high abundance of wolves. Another noteworthy option is the reintroduction of reindeer into regions where the wolf still exists at low densities.
\end{abstract}

\section{Introduction}

When a managed ecosystem hosts an endangered predator that preys on an endangered prey species it is essential to evaluate the role of predation when making management decisions (Jhala 1993). The most well-known cases con- cern introduced exotic predators that can cause extinction of endemic prey species (Sinclair et al. 1998). Furthermore, human activities such as forestry modify the age structure of forests and the spatial structure of the forest landscape, and may thereby influence predator-prey interactions by favouring some herbivores species 
at the expense of others. In the boreal forest ecosystem, one of the winners seems to be the moose (Alces alces), while one of the losers seems to be the wild reindeer (Rangifer tarandus; Seip 1992, Rempel et al. 1997, COSEWIC 2002, James et al. 2004). Forest harvesting has reduced the age structure of forests and created more moose habitats, leading to a current wild reindeer conservation problem (Lessard et al. 2005, Courtois \& Quellet 2007). Over most of the boreal forest region, wolves mainly depend on moose (Mech \& Peterson 2003), and since the number of moose has increased the number of wolves has also increased.

Predation is therefore a potential reason for the observed decrease in wild reindeer populations (Bergerud \& Ballard 1988, Bergerud \& Elliott 1998, Wittmer et al. 2005). In declining populations the recruitment rate is usually low, owing to high mortality in the youngest age class (Bergerud \& Elliott 1998, McLoughlin et al. 2003).

In Finland there are two small wild-forest reindeer (R.t.fennicus) populations, each presently consisting of about 1000 individuals. Of these populations, the western one has been slightly increasing and the eastern one decreasing during recent years, and the total number of wild reindeer in Finland is about 30\% lower than it was around 2001-2002 (Kojola 2007).

In the latest red list of Finnish threatened species, the wolf (Canis lupus) is classified as an endangered species (Rassi et al. 2001). The report states that the number of breeding individuals is so low $(<50)$ that the wolf ought to be classified as critically endangered. However, it was down-listed because it is generally considered that Finland's wolf population continuously receives dispersers from Russia. A recent genetic study indicates, however, that only a few wolves have emigrated from Russia during recent years (Aspi et al. 2009). Our aim was therefore to examine the reasons for the recent, substantial decrease in the wild-forest reindeer population in eastern Finland, considering wolf predation as one of the potential reasons for the decline, and to discuss alternative management and conservation options to improve the status of wild forest reindeer in Europe.

\section{Material and methods}

\section{Study area}

The total population range of the wild-forest reindeer is about $8000 \mathrm{~km}^{2}$. This area belongs to the mid-boreal forest zone (Ahti et al. 1968). Scots pine (Pinus sylvestris) and Norway spruce (Picea abies) are the dominant tree species. Bogs are common and the topography is flat; the altitude varies mainly from 100 to $200 \mathrm{~m}$ a.s.l. The proportion of protected, old-growth forests is $<3 \%$ of the forested area in the population range. Extensive logging and peatland drainage has considerably changed the habitat mosaic from the original landscape structure. These changes have been favorable for the moose, which prefers stands in the early succession stage.

\section{Reindeer}

The wild-forest reindeer was counted in the years 1996, 1999, 2001, 2003, 2005, 2007, and 2008. Counts were made from helicopters within one week in early March. During this season, reindeer are gathered in their winter ranges, which usually cover $10 \%-20 \%$ of the total population range (Heikura et al. 1986, Kojola et al. 2004).

Data on the population structure were systematically collected by ground observations made during the winters of 1996/1997 to 2007/2008 (12 years). The data were divided into two periods: early winter (October-December) and late winter (January-April). In this paper, we regard the calf/female ratio in late winter as a measure of the recruitment rate. The mean number of females ( \pm SE) observed was $393 \pm 53$ in the early winter, and $486 \pm 148$ in the late winter. Annual differences in the calf/female ratio were highly significant both in the early and late winter $\left(\chi^{2}=97.03\right.$, df $=10, P<0.001$; $\chi^{2}=51.32, \mathrm{df}=10, P<0.001$, respectively). The calf/female ratios in the early and late winter were strongly correlated (Pearson's $r=0.913$, $n=10$ years, $P<0.001)$. Early-winter observations for 2002 and late-winter observations for 1999 were not available. We adjusted the calf/ female ratio for these years by using the mean 
difference between the observation periods. On average, 0.079 more calves per female were observed during the first period than the second.

During 2004-2007, 38 female reindeer were captured and collared with global positioning system (GPS) and global system for mobile (GSM) transmitters. These animals were baited to corrals constructed in their winter habitats using dry hay as the bait. Altogether, 51 animals were monitored for reproduction in order to calculate the calving percentage. Calving was confirmed by observing females at 1- to 3-day intervals. For 30 of the resulting calves that disappeared during the summer $(\leq 80$ days from birth), the day of birth was known, as was the day of disappearance to within \pm 2 days. Direct observation of reindeer is easier than with most other forest-dwelling ungulates because they prefer open bogs as their summer habitat (Helle 1980). As reindeer calves mostly stay in the vicinity of their mothers, the presence of a calf can be readily assessed. However, the reason for calf deaths could not be confirmed. We calculated a Kaplan-Meier estimate for calf survival (Krebs 1989: pp. 439-440).

The reproductive rate of reindeer can be influenced by snow conditions (e.g. Helle \& Kojola 2008). We obtained daily snow depth measurements from a meteorological station located at the centre of the wild reindeer range (Kuhmo), and calculated the cumulative snow sum index (the cumulative sum of the daily snow depths) and the day of snowmelt (the number of days that had passed after April 1) from this database.

\section{Wolf}

Our estimate for the wolf density was the number of wolves in early winter per $1000 \mathrm{~km}^{2}$ of the total area used by wild reindeer in eastcentral Finland. The calf/female ratio in late winter was regressed against this estimate. A wolf census was performed by mapping the territories of packs and territory-marking pairs by means of radio and GPS transmitters, and snowtracking. The study area was thoroughly scanned each study year by moose hunters during the October-December moose hunting season. Their findings provided one important basis for our field investigations. We used logging roads that exist at some kilometers distance when searching for fresh tracks for backtracking. The number of wolves in each pack was assessed by snow-tracking. During 1998-2007 we equipped 26 wolves in 5 packs with a radio or GPS transmitter. The capture techniques are described in detail elsewhere (Kojola et al. 2006). Territory boundaries were defined by tracking radio-collared wolves 2 times per week and downloading GPS positions (6 locations per day) using the GSM connection to the transmitter. The yearly proportion of territories with at least one collared wolf during 1998-2007 was as follows: $1.0,1.0,1.0,0.7,0.7,0.5,0.5,0.3,0.4$, and 0.6 , respectively. We counted the sum of wolves in packs, territory-marking pairs and single residents within the distribution range of wild forest reindeer. The estimate for the total number of wolves is based on the assumption that such wolves represented $90 \%$ of the wolves living in the area, according to the mean proportion of resident wolves in North American populations (Fuller et al. 2003). On the basis of the movements of collared female reindeer (J. Tuomivaara unpubl. data), we assumed the total area used by our study population of reindeer to remain constant $\left(8000 \mathrm{~km}^{2}\right)$ throughout the study period (1996-2008).

\section{Results}

The number of reindeer had increased from 1000 to 1700 during 1996-2001 (i.e. by 11\% per year) but decreased thereafter by $10 \%$ per year, resulting in 880 animals in 2008 (Fig. 1). The calf/female ratio decreased from 0.4 close to 0.2 during the study (Fig. 2). During 2004-2007, after the return of wolves, the percentage of calving females was $94.1(n=51)$, but only one third of the calves survived $>80$ days. The survival curve was linear during these 80 days (Fig. 3).

The abundance of wolves increased five-fold during 1996-2007 (Fig. 4).The pack size peaked in 2000 when there were 35 wolves in three packs. Of these wolves, 20 animals were pups of the year. The number of territories occupied by packs or pairs peaked in 2006 (Fig. 4).

In a linear regression model (calves/females 


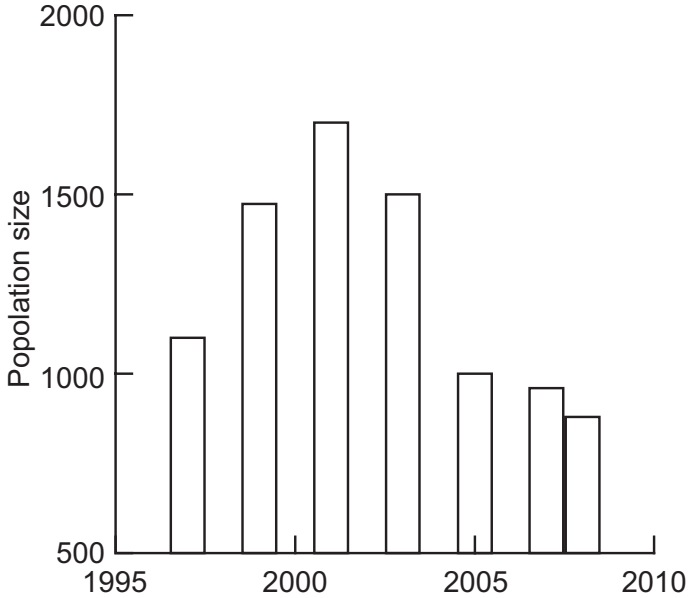

Fig. 1. Development of the wild reindeer population during 1997-2008, eastern Finland.

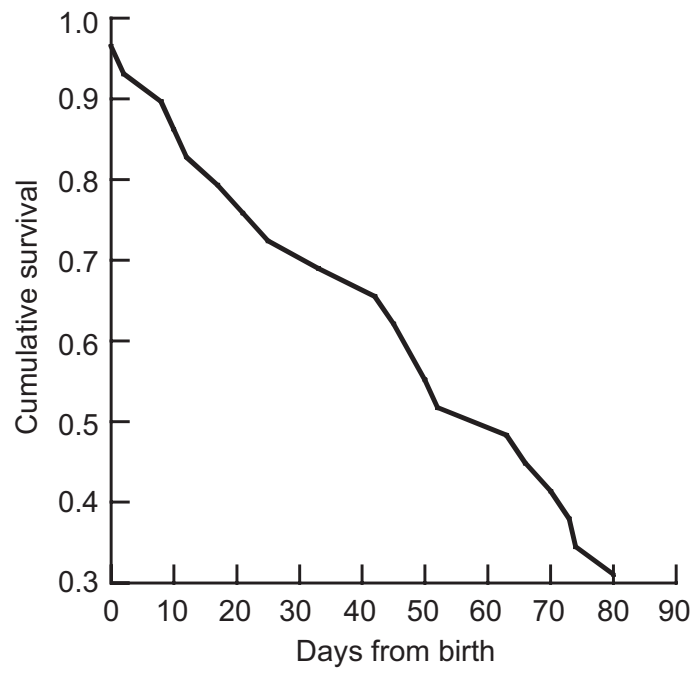

Fig. 3. Survival of wild reindeer calves during the summer, 2004-2007, eastern Finland.

$=0.403-0.044$ wolves $/ 1000 \mathrm{~km}^{2}$ ), wolf density explained $69 \%$ of the variation in the calf/female ratio in late winter (Fig. 5). The calf/female ratio depended significantly on wolf density $\left(F_{1,10}=\right.$ $25.06, P=0.001)$ and increased with an increasing reindeer/wolf ratio (calves/females $=0.207+$ 0.001 reindeer/wolves, adjusted $R^{2}=0.94, F_{1,5}=$ 97.41, $P<0.001$, Fig. 6). The calf/female ratio did not depend on either the previous winter's snow depth index $\left(F_{1,10}=1.92, P=0.199\right)$ or the day of snowmelt $\left(F_{1,10}=3.02, P=0.116\right)$.

Lynx (Lynx lynx) also prey on wild reindeer, but during the ground-tracking of reindeer in the

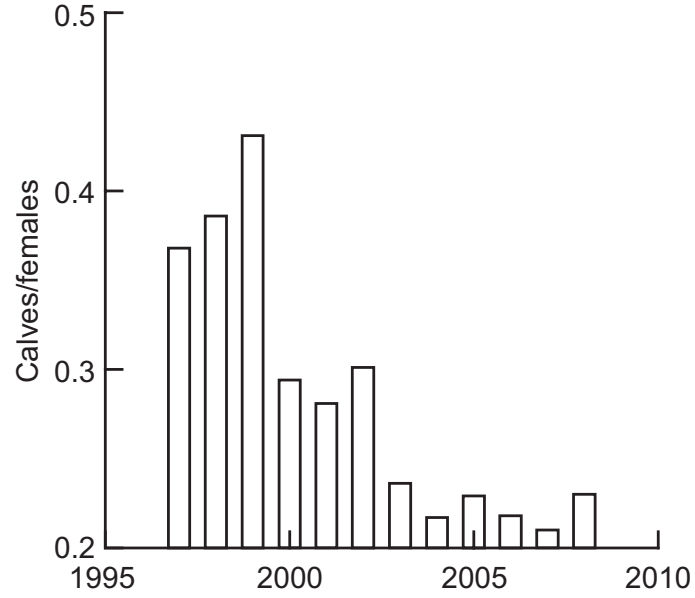

Fig. 2. The calf/female ratio in wild reindeer during 1997-2008, eastern Finland.
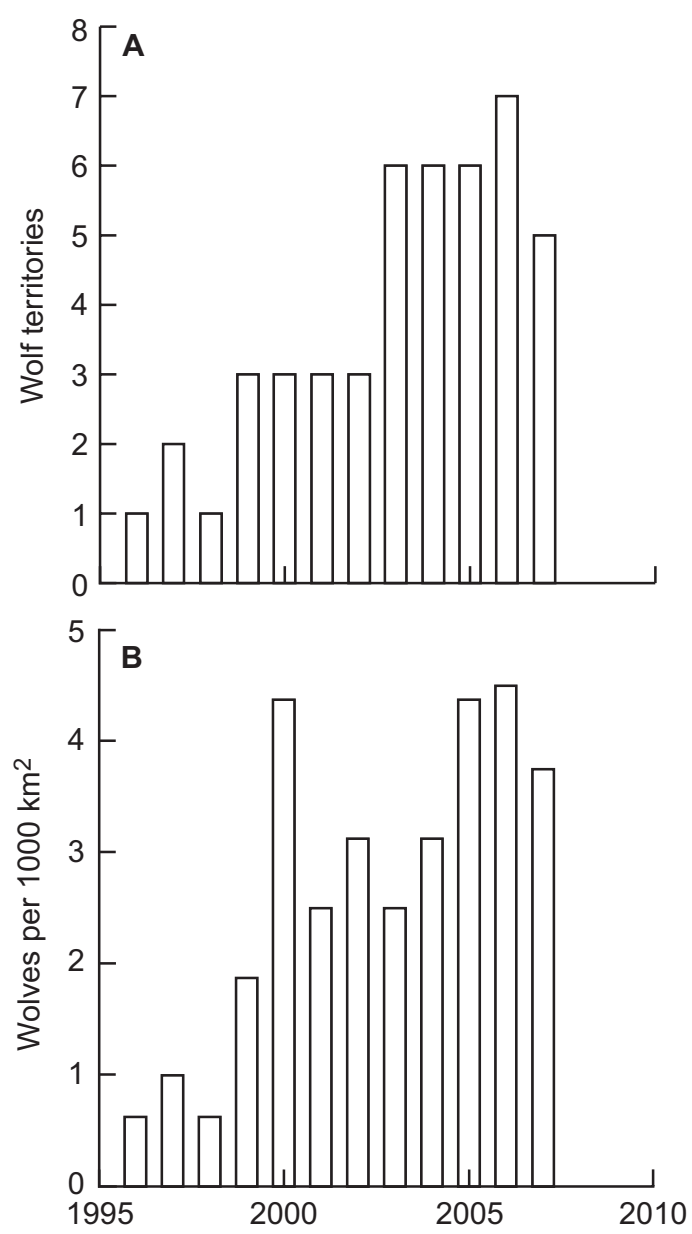

Fig. 4. (A) The number of wolf territories occupied by packs or pairs, and $(\mathbf{B})$ the estimated density of wolves in early winter, 1996-2007, eastern Finland. 


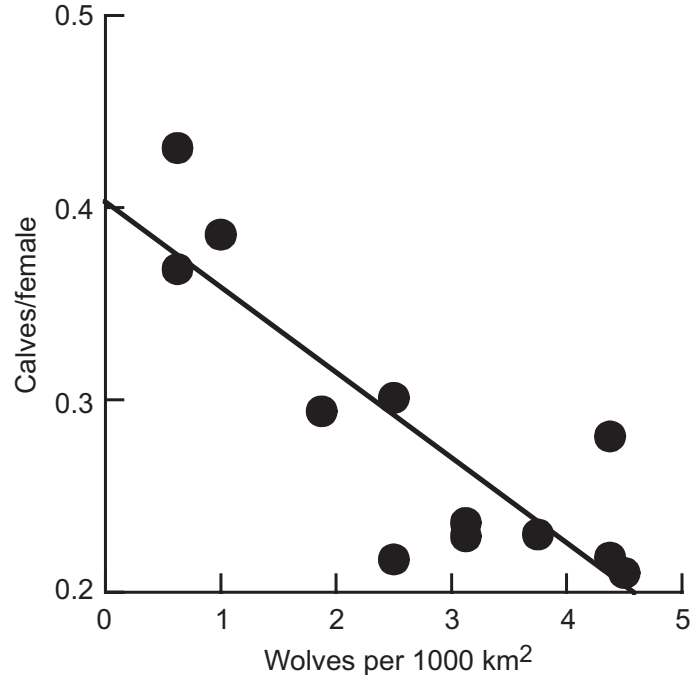

Fig. 5. The relationship between the density of wolf population and the calf/female ratio in wild reindeer during 1997-2008, eastern Finland.

winter, more wolf-killed (48) than lynx-killed (18) reindeer were found. Only in 2004 were lynx-killed reindeer more numerous (10) than wolf-killed ones (3). No reindeer killed by wolverines (Gulo gulo) were observed.

\section{Discussion}

The future of wild forest reindeer in Europe is uncertain because the largest populations (our study population and that in Russian Karelia; Danilov 2003) have been declining in recent years, but the reasons for this have remained unclear. Our data show the same pattern, with an annual decrease in reindeer of almost $10 \%$. This is probably because the recruitment rate in eastern Finland was low due to the high mortality of calves in recent summers. Similarly, in British Columbia (Bergerud \& Elliot 1998) and in Alberta (McLoughlin et al. 2003), reindeer populations have declined while recruitment rates have been as low as 20 calves per 100 females, as was the case in eastern Finland. In western Finland, where the introduced population has been increasing, the proportion of calves is twice that observed in the eastern population (M. Rautiainen unpubl. data).

Our results provide evidence that the increased wolf density could be a prominent

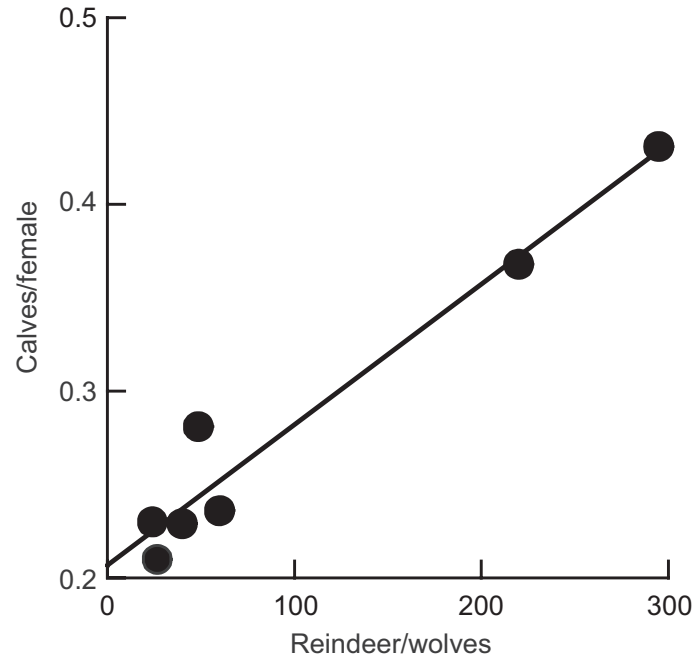

Fig. 6. The relationship between the reindeer/wolf ratio and calf/female ratio in wild reindeer during 1997-2008, eastern Finland.

reason for the reindeer population decrease. In years when wolves were common, the calf/ female ratio was two times lower than in years when wolves were scarce. However, correlative data are not conclusive and there might be other reasons for the high calf mortality. The most likely of these include predation by the brown bear (Ursus arctos) and lynx (Lynx lynx) or the poor physical condition of females.

However, it is unlikely that the other two predators could be behind the observed decline in the wild forest reindeer population. Based on genetic analysis of scats collected by hunters in 2005, the minimum density of the bear population was 10 animals $/ 1000 \mathrm{~km}^{2}$ (A. Kopatz unpubl. data). The linearity of the survival graph (Fig. 3) indicates that the brown bear would play a smaller role than the wolf because the bear shifts to a plant-dominated diet in early summer (Dahle et al. 1998). Extensive studies using silent mortality transmitters in semi-domesticated reindeer ( $R$. $t$. tarandus) have demonstrated that when predation by brown bear is the primary cause of death, survival shows a pronounced low during the first weeks after birth (Norberg et al. 2007). Lynx density was lower than the wolf density (estimated at $2-4$ animals $/ 1000 \mathrm{~km}^{2}$; Kojola et al. 2006). The primary prey of lynx in eastern Finland is the mountain hare, which constitutes $80 \%$ of its winter diet (Pulliainen et al. 1995). 
It is also unlikely that the female condition alone could explain the observed pattern. We did not have comprehensive data on the variation in the physical condition of female reindeer, but our analysis provided evidence that adverse winter conditions were not a reason for the low recruitment rate in our study area. In the last years of the study period the snow depths were somewhat less and the snow melted earlier than in the late 1990s (I. Kojola unpubl. data). The biomasses of the main winter forage, ground lichens (Cladina spp.), were also high in our study area (Heikura 1998). This held true even at the most heavily exploited sites, and reindeer have been able to find new, practically untouched winter ranges (Heikura 1998). The population density remained as low as 0.2 animals $/ \mathrm{km}^{2}$ even at the population peak. Furthermore, the linear shape of the survival graph did not refer to malnutrition of females, because the calves born to females in poor physical condition die during the first few days after birth (Eloranta \& Nieminen 1986).

\section{Conservation and management implications}

There are basically two policy options for avoiding the extinction of wild forest reindeer: to directly control the predation risk or to control factors in the ecosystem that have led to a high abundance of predators. The moose is much better able than wild reindeer and caribou to support abundant wolf populations in boreal forests owing to its larger size and because it usually exists at higher densities. Simulation models by Lessard et al. (2005) and Courtois and Quellet (2007) indicate that a management scheme aimed at lowering the extinction risk of woodland caribou should include control over the abundance of both wolves and moose. On the other hand, Weclaw and Hudson (2004) argued that boreal caribou would survive even with uncontrolled wolf populations but at very low densities $(0.01$ caribou $/ \mathrm{km}^{2}$ ). In addition to management actions that involve management of the local abundance of wolf and moose, re-introductions of wild forest reindeer into regions where the predation risk is lower is a noteworthy option to reduce the extinction risk of wild reindeer in Finland. Re-intro- ductions can be an effective means of restoration (Bergerud \& Mercer 1989, Kojola 1993). However, Bergerud and Mercer (1989) suggested that woodland caribou cannot return to their old natural ranges if there are high wolf numbers. In Finland, the regions located approximately midway between the western and eastern populations of wild reindeer are probably the most appropriate. These areas host only few wolf packs and could bridge the contemporary populations in the future, thereby increasing the demographic and genetic viability of wild forest reindeer.

Increasing the control of wolves to reduce the predation rate in the eastern range is a controversial issue because the number of breeders in the Finnish wolf population is only about 40 animals (Aspi et al. 2006). The high reproductive potential and recent expansion of the wolf population (Kojola 2005), on the other hand, would provide room for controlling the number of wolves in the wild reindeer core areas in eastern Finland. One potential direct management action is increased wolf control in the primary summer home ranges of female reindeer. In the long term, wolf predation on wild forest reindeer would decline if the abundance of moose (Alces alces) could be lowered, because a high moose density supports a high abundance of wolves.

\section{Acknowledgements}

Several people took part in capturing, radio-tracking and snow-tracking the wolves in Finland. We would like to acknowledge all of them.

\section{References}

Aspi, J., Roininen, E., Kiiskilä, J., Ruokonen, M., Kojola, I., Bljudnik, L., Danilov, P., Heikkinen, S. \& Pulliainen, E. 2009: Genetic structure of the northwestern Russian wolf populations and gene flow between Russia and Finland. - Conservation Genetics 10: 815-826.

Aspi, J., Roininen, E., Ruokonen, M., Kojola, I. \& Vila, C. 2006: Genetic diversity, population structure, effective population size and demographic history of the Finnish wolf population. - Molecular Ecology 15: 1561-1576.

Ahti, T., Hämet-Ahti, L. \& Jalas, J. 1968: Vegetation zones and their sections in northwestern Europe. - Annales Botanici Fennici 5: 169-211.

Bergerud, A. T. \& Elliott, J. B. 1998: Wolf predation in a multiple-ungulate system in northern British Columbia. 
- Canadian Journal of Zoology 76: 1551-1569.

Bergerud, A. T. \& Mercer, W. E. 1989: Caribou introductions in eastern North America. - Wildlife Society Bulletin 17: $111-120$.

COSEWIC 2002: Assessment and update status report on the woodland caribou Rangifer tarandus caribou. COSEWIC Committee on the status of endangered wildlife of Canada.

Courtois, R. \& Quellet, J. P. 2007: Modeling the impact of moose and wolf management on persistence of woodland caribou. - Alces 43: 13-28.

Dahle, B., Sørensen, O. J., Wedul, E. H., Swenson, J. E. \& Sandegren, F. 1998: The diet of brown bears Ursus arctos in central Scandinavia: effect of access to freeranging domestic sheep Ovis aries. - Wildlife Biology 4: $147-158$.

Eloranta, E. \& Nieminen, M. 1986: Calving of the experimental reindeer herd in Kaamanen during 1970-85. Rangifer, Special Issue 1: 115-121.

Fuller, T. K., Mech, D. \& Cochrane, J. F. 2003: Wolf population dynamics. - In: Mech, L. D. \& Boitani, L. (eds.), Wolves, behavior, ecology, and conservation: 161-191. The University of Chicago Press, Chicago.

Heikura, K. 1998: The lichen resources, their use, and the wintering grounds of the wild forest reindeer (Rangifer tarandus fennicus Lönnb.) in the Kuhmo-Kamennojeozero subpopulation. - In: Danilov, P. I. (ed.), Dynamics of game animal populations in northern Europe, 2nd Int. Symp.: 27-32. Russian Academy of Sciences, Karelian Research Center, Petrozavodsk, Russia.

Heikura, K., Pulliainen, E., Danilov, P. I., Erkinaro, E., Markovsky, V. A., Bljudnik, L., Sulkava, S. \& Lindgren, E. 1986: Wild forest reindeer, Rangifer tarandus fennicus Lönnb., its historical and recent occurrence and distribution in Finland and the Karelian ASSR (USSR) with special reference to the development and movements of the Kuhmo (Finland)-Kamennojeozero (USSR) subpopulation. - Aquilo, Series Zoologica 23: 22-45.

Helle, T. 1980: Studies on wild forest reindeer (Rangifer tarandus fennicus Lönn.) and semi-domestic reindeer (Rangifer tarandus tarandus L.) in Finland. - Acta Universitas Oulu A 107: 1-33.

Helle, T. \& Kojola, I. 2008: Demographics in an alpine reindeer herd: effects of density and winter weather. Ecography 31: 221-230.

James, A. R., Boutin, S., Hebert, D. M. \& Pippin, A. B. 2004: Spatial separation of caribou from moose and its relation to predation by wolves. - Journal of Wildlife Management 68: 799-809.

Jhala, Y. V. 1993: Predation on blackbuck by wolves in Velavadar National Park, Gujarat, India. - Conservation Biology 7: 874-881.

Kojola, I. 1993: Ecology of reindeer introductions. Suomen Riista 39: 74-84. [In Finnish with English summary].

Kojola, I. 2005: The biology of wolf and the viability of wolf population. - In: Management plan for the wolf in Finland: 8-15. Ministry of Agriculture and Forestry,
Finland.

Kojola, I. 2007: The impact of large carnivores on wild forest reindeer populations in Finland. - Suomen Riista 53: 42- 48. [In Finnish with English summary].

Kojola, I., Aspi, J., Hakala, A., Heikkinen, S., Ilmoni, C. \& Ronkainen S. 2006: Dispersal in an expanding wolf population in Finland. - Journal of Mammalogy 87: 281-286.

Kojola, I., Huitu, O., Toppinen, K., Heikura, K., Heikkinen, S. \& Ronkainen, S. 2004: Predation on European wild forest reindeer (Rangifer tarandus) by wolves (Canis lupus) in Finland. - Journal of Zoology 263: 229-235.

Krebs, C. J. 1989: Ecological methodology. - Harper and Row Publishers, New York.

Lessard, R. B., Martell, S. J. D., Walters, C. J., Essington, T. E. \& Kitchell, J. F. 2005: Should ecosystem management involve active control of species abundances? - Ecology and Society 10(2), http://www.ecologyandsociety. org/vol10/iss2/art1/.

McLoughlin, P. D., Dzus, E., Wynes, B. \& Boutin, S. 2003: Declines in populations of woodland caribou. - Journal of Wildlife Management 67: 755-761.

Mech, L. D. \& Peterson, R. O. 2003: Wolf-prey relations. In: Mech, L. D. \& Boitani, L. (eds.), Wolves, behavior, ecology and conservation: 131-160. University of Chicago Press, Chicago.

Norberg, H., Nieminen, M. \& Maijala, V. 2002: Brown bear predation on semi-domesticated reindeer in Finland. - In: Kvam, T. \& Sörensen, O. J. (eds.), Living with bears, 14th International Conference of Bear Research and Management, Steinkjer, Norway 2002: 103. NordTrøndelag University College, Steinkjer, Norway.

Pulliainen, E., Lindgren, E. \& Tunkkari, E. 1995: Influence of food availability and reproductive status on the diet and body condition of the European lynx in Finland. Acta Theriologica. 40: 181-196.

Rassi, P., Alanen, A., Kanerva, T. \& Mannerkoski, I. 2001. Suomen lajien uhanalaisuus 2000. - Ministry of Environment and Environmental Research Center of Finland, Helsinki.

Rempel, R. S., Elkie, P. C., Rodgers, A. R. \& Cluck, M. J. 1997: Timber management and natural disturbance effects on moose habitat: landscape evaluation. - Journal of Wildlife Management 61: 517-524.

Seip, D. R. 1992: Factors limiting woodland caribou and their interrelationships with wolves and moose in southeastern British Columbia. - Canadian Journal of Zoology 70: 1491-1503.

Sinclair, A. R. E., Pech, R. P., Dickman, C. R., Hik, D., Mahon, P. \& Newsome, A. E. 1998: Predicting effects of predation on conservation of endangered prey. - Conservation Biology 12: 564-575.

Weclaw, P. \& Hudson, R. J. 2004: Simulation of conservation and management of woodland caribou. - Ecological Modelling 177: 75-94.

Wittmer, H. U., Sinclair, A. R. E. \& McLellan, B. 2005: The role of predation in the decline and extirpation of woodland caribou. - Oecologia 144: 257-267. 